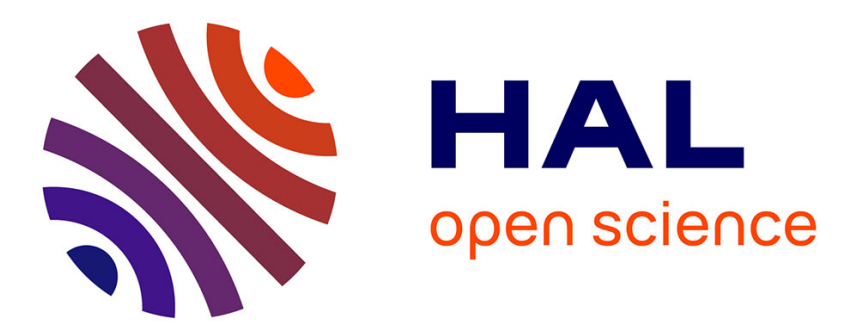

\title{
Josephson detectors of millimeter electromagnetic radiation
}

\author{
V.A. Kulikov, N.N. Kurdjumov, G.F. Leshchenko, L.V. Matveets, V.V. \\ Migulin, E.S. Soldatov
}

\section{- To cite this version:}

V.A. Kulikov, N.N. Kurdjumov, G.F. Leshchenko, L.V. Matveets, V.V. Migulin, et al.. Josephson detectors of millimeter electromagnetic radiation. Revue de Physique Appliquée, 1974, 9 (1), pp.293294. 10.1051/rphysap:0197400901029300 . jpa-00243757

\section{HAL Id: jpa-00243757 https://hal.science/jpa-00243757}

Submitted on 1 Jan 1974

HAL is a multi-disciplinary open access archive for the deposit and dissemination of scientific research documents, whether they are published or not. The documents may come from teaching and research institutions in France or abroad, or from public or private research centers.
L'archive ouverte pluridisciplinaire HAL, est destinée au dépôt et à la diffusion de documents scientifiques de niveau recherche, publiés ou non, émanant des établissements d'enseignement et de recherche français ou étrangers, des laboratoires publics ou privés. 


\title{
JOSEPHSON DETECTORS OF MILLIMETER ELECTROMAGNETIC RADIATION
}

\author{
V. A. KULIKOV, N. N. KURDJUMOV, G. F. LESHCHENKO \\ L. V. MATVEETS, V. V. MIGULIN and E. S. SOLDATOV \\ Institute of Terrestrial Magnetism \\ Ionosphere and Radio Wave Propagation (IZMIRAN) \\ PO, Academgorodok, Moscow region, USSR
}

\begin{abstract}
Résumé. - Nous étudions en détail la possibilité de réaliser des détecteurs de rayonnements électromagnétiques en utilisant des contacts ponctuels présentant un effet Josephson.

Cette communication est consacrée aux détecteurs millimétriques utilisés en radioastronomie pour l'étude du spectre des objets célestes.

Abstract. - The possibility of construction of high sensitive detectors of electromagnetic radiation on the base of Josephson point contacts have been studied in detail [1], [2], [3], [4].

This communication is devoted to detectors of electromagnetic radiation in the upper millimeter range, designed for use in radioastronomy, in particular for experimental investigation of radiation spectra of celestial objects.
\end{abstract}

Owing to special conditions needed for these experiments and their technical requirements, it has been taken into account while making these detectors, not only the achievement of maximum sensitivity, but also the stability of the detector's electrical characteristics when subjected to several temperature cycles between $300 \mathrm{~K}$ and $4.2 \mathrm{~K}$ and the possibility of their easy matching with external electrodynamic systems.

With this view in mind the construction of these detectors was based on two types of weak link superconducting systems. In one case a detector was formed with a single Josephson point contact, and in the other with compressed superconducting grains. The general view of the detectors of both types is shown in figure 1 .

Single Josephson point contacts were made by forming electrical contact between two $\mathrm{Nb}$ electrodes : one of them was needle-shaped, and the other almost plane. The needle electrodes were prepared by means of electrochemical etching or by a mechanical process. Initial detector characteristics were not found to depend on the kind of procedure, but characteristics of detectors with etched electrodes tended to grow worse with time.

The electrical parameters of the single point contact detectors are as follows : asymptotic resistances at $4.2 \mathrm{~K}$ are about 15 to $30 \mathrm{ohms}$, characteristic voltages of different samples range from $5 \times 10^{2}$ to $1.7 \times 10^{3} \mu \mathrm{V}$ at critical currents $I_{\mathrm{c}}$ of 10 to $100 \mu \mathrm{A}$. The ohmic resistance was found to decrease down to $30 \%$ when cooling the contacts from room temperature to the helium one. The response of the single point contact detectors is about $5 \times 10^{4} \mathrm{~V} / \mathrm{W}$.

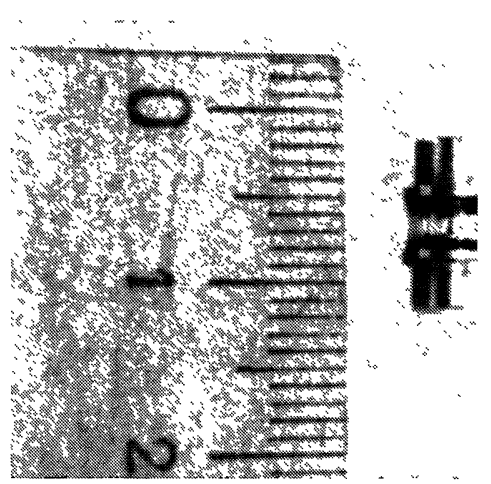

FIG. 1. - The general view of the detector.

The stability of the junction electrical characteristics even with temperature cyclings from $300 \mathrm{~K}$ to $4.2 \mathrm{~K}$ and their protection from external mechanical disturbances were provided by placing the junctions in a metallic-glass capsule, by a special choice of the case materials and by methods of fixing superconducting electrodes. In order to fixing the electrodes and to prevent their displacement under vibration, the needle electrode was stressed on the other electrode which was concave.

As a result of these actions, electrical parameters of the detectors still remained constant during more than twenty temperature cyclings and under considerable vibration and mechanical impacts.

The detectors on bulk granular superconductors were made by placing niobium grains of $\sim 30$ microns 
in diameter into a $2-3 \mathrm{~mm}$ long glass capillaries of $\sim 100$ microns internal diameter. Then the capillary was set into the capsule. Prior to this the powder which was chemically treated with a mixture of acids was not specially heat treated.

The room temperature resistance of the samples was about 200 to $250 \mathrm{ohms}$. When cooled to a temperature of $4.2 \mathrm{~K}$ the resistance change was less than 10 to $15 \%$, the critical current being about $10 \mu \mathrm{A}$. Responses of these detectors were in the range of $10^{3}$ to $10^{5} \mathrm{~V} / \mathrm{W}$. The ultimate stabilization of detector parameters was achieved after several temperature cyclings. The change of detector parameters during these cyclings seems to be related to uncontrolled redistributions of granules in the capillary.

The use of the same capsules for both types of detectors and the choice of optimum relation of capsule sizes to waveguide dimensions allowed us to build easy matching detectors with waveguides in the range under investigation. Impedance matching of the detector with the waveguide was approached by tuning the stub.

Moreover, the insertion of superconducting systems in the same capsules prevents the junctions from environment effects, thus makes them easy to manipulate, standardizes the detector sizes and creates the base for their commercial production.

\section{References}

[1] Grimes, C. C., Richards, P. L., Shapiro, S., Phys. Rev. Lett. 17 (1966) 431.

[2] Richards, P. L., Sterling, S. A., J. Appl. Phys. 14 (1969) 394.

[3] Warman, J., Jahn, H. T., KaO, J. H., J. Appl. Phys. 42 (1971) 5194.

[4] Kanter, H., Vernon, F. L., J. Appl. Phys. 43 (1972) 3174. 